\title{
MADREPORA MUSICALIS.
}

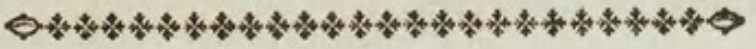

CHARACTER GENERICUS.

Animal Medufa.

Corallium cavitatibus lamellofo-ftellatis.

$$
\text { Lin. Syf. Nat. p. } 1272 .
$$

Character SPECificus, Ec.

MADREPORA aggregata, cylindris fuberectis Atriatis, diffepimentis tranfverfis diftantibus.

MADREPORA aggregata, cylindris ftellarum ftriatis diftantibus combinatis membranis tranfverfis.

$$
\text { Soland et Ell. zooph. p. } 165 \text {. }
$$

MI. coralliis cylindricis ftriatis diftantibus, combinatis, membranis confertiffimis tranfverfis.

$$
\text { Lin. Syf. Nat. Gmel. p. } 3769 \text {. }
$$

Infignis corallii veram magnitudinem depinximus, adeo conformati ut genera Tubipore et Madrepore connectere quodammodo videatur; cum columnx feu cylindri certo intervallo diffepimentis tranfverfis inter fe conjungantur. Licet in oceano Indico innafcatur, interdum tamen reperta funt fpecimina in 
oris Britannicis. Recens rarifimum; in lapideam duritiem converfum fæpius e terra effoditur quam reliqua pleraque corallia. 



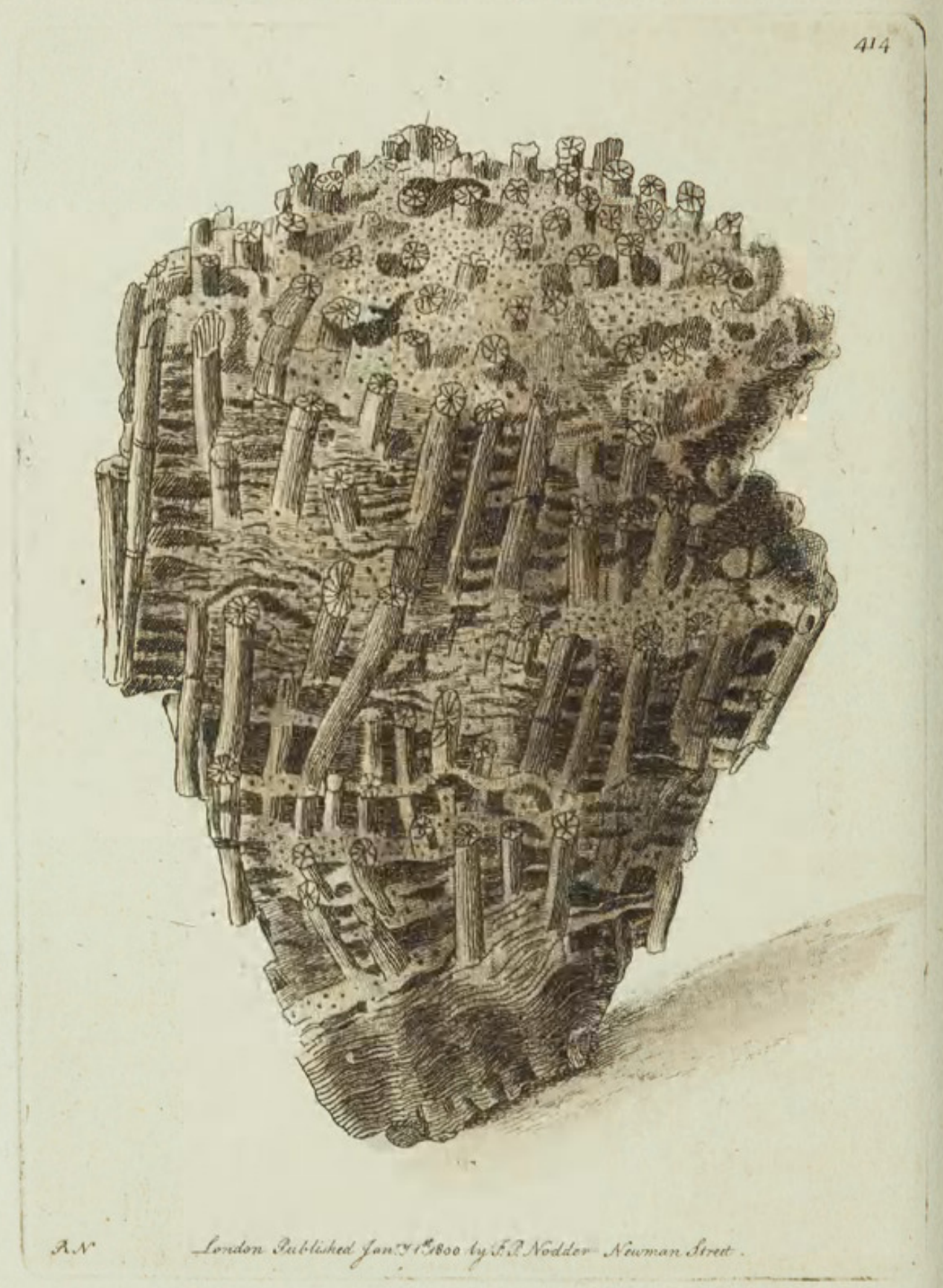




\section{ORGAN MADREPORE.}

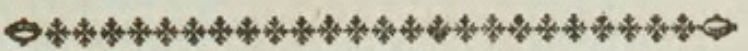

\section{GENERIC CHARACTER.}

Animal refembling a Medufa.

Coral marked with lamellar ftriated cavities.

\section{SPECIFIC CHARACTER, छृC.}

Aggregated MADREPORE, with fuberect friated diftant cylinders, with tranfverfe diffepiments.

White Organ Coral.

Fafciated Coral.

Borl. Cornw. p. 241.pl. 27. f. 7 .

The curious Coral here reprefented in its natural fize, feems to connect the genera of Tubipore and Madrepore, having the columns, of which it is compofed, united at intervals by tranfverfe diffepiments. It is a native of the Indian ocean, and is confidered as a rare fpecies recent, tho' more common in a foffil or petrified ftate than moft others. 


\section{$2 \mathrm{BHL}$ Biodiversity Heritage Library}

Shaw, George. 1800. "Organ Madrepore, Madrepora musicalis [PI. 414]." The Naturalist's Miscellany 11(CXXVI), https://doi.org/10.5962/p.310861.

View This Item Online: https://www.biodiversitylibrary.org/item/276496

DOI: https://doi.org/10.5962/p.310861

Permalink: https://www.biodiversitylibrary.org/partpdf/310861

\section{Holding Institution}

Museums Victoria

\section{Sponsored by}

Atlas of Living Australia

\section{Copyright \& Reuse}

Copyright Status: Public domain. The BHL considers that this work is no longer under copyright protection.

This document was created from content at the Biodiversity Heritage Library, the world's largest open access digital library for biodiversity literature and archives. Visit BHL at https://www.biodiversitylibrary.org. 